their weight, which was still considerable, would not be objectionable. The secondary battery was not an entirely new conception. The hydrogen gas battery suggested by Sir Wm. Grove in $184 \mathrm{I}$, and which was shown in operation, realised in the most ferfect manner the conception of storage, only that the power obtained from it was exceedingly slight. The lecturer, in working upon Sir William Grove's conception, had twenty-five years ago constructed a battery of considerable power in substituting porous carbon for platinum, impregnating the same with a precipitate of lead peroxidised by a charging current. At that time little practical importance attached, however, to the subject, and even when Planté, in 1860 , produced his secondary battery, composed of lead plates peroxidised by a charging current, little more than scientific curiosity was excited. It was only since the dynamo-machine had become an accomplished fact that the importance of this mode of storing energy had become of practical importance, and great credit was due to Faure, to Sellon, and to Volckmar, for putting this valuable addition to practical science into available forms. A question of great interest in connection with the secondary battery had reference to its permanence. A fear had been expressed by many that local action would soon destroy the fabric of which it was composed, and that the active surfaces would become coated with sulphate of lead preventing further action. It had, however, lately been proved in a paper read by Dr. Frankland before the Royal Society, corroborated by simultaneous investigations by Dr. Glad-tone and Mr. Tribe, that the action of the secondary battery depended essentially upon the alternative composition and decomposițion of sulphate of lead, which was therefore not an enemy, but the best friend to its continued action.

In conclusion, the lecturer referred to electric nomenclature, and to the means for measuring and recording the passage of electric energy. When he addressed the British Association at Soutbampton, he had ventured to suggest two electrical units additional to those established at the Electrical Congress in 188I, viz., the Watt and the Joule, in order to complete the chain of units connecting electrical with mechanical energy and with the unit-quantity of heat. He was glad to find that this suggestion had met with favourable reception, especially that of the Watt, which was convenient for expressing in an intelligible manner the effective power of a dynamo-machine, alid for giving a precise idea of the number of lights or effective power to be realised by its current, as well as of the engine power necessary to drive it : 746 Watts represented I h.p.

Finally the Watt-meter, an instrument recently developed by his firm, was shown in operation. This consisted simply of a coil of thick conductor suspended by a torsion wire, and opposed laterally to a fixed coil of wire of high resi-tance. The current to be measured flowed through both coils in parallel circuit, the one representing its quantity expressible in Ampères, and the ther its potential expressible in Volts. Their joint attractive action expressed therefore Volt-Ampères or Watts, which were read off upon a scale of equal divisions.

The lecture was illustrated by experiments, and by numerous diagrams and tables of results. Measuring instruments by Professors Ayrton and Perry, by Mr. Edison and by Mr. Boys were also exhibited.

\section{FAUNA AND FLORA OF THE ALEUTIAN} ISLANDS

THE last number of Naturen contains an interesting report by Dr. Leonhard Stejneger of the result of his six months observations of the fauna and flora of the Kamschatkan coast and of the so-called Kommandorski Islands, which form the western group of the Aleutian archipelago between Behring's Sea and the Pacific, in $50^{\circ}-55^{\circ} \mathrm{N}$. lat. The Kommandorski group consists of two islands, one of which is known as Medno Ostrov, Copper Island, from the large amount of the pure metal found there ; while the other, which was the scene of Behring's shipwreck and death, bears his name. Both islands are geologically allied to Kamschatka, and excepting at the north of Behring's Island, where the gradual subsidence of the sea has left raised beaches, terraces, and tabulated rock-formations, the islands consist generally of deep narrow valleys separated by rocky barriers, which ri:e precipitously to a beight of from Iooo to 2000 feet above the level of the sea. The islands, which were uninhabited before their annexation by Russia, are now occupied by about 700 persons, in the employment of a Russo-
American fur company, which has been attracted to the spot by the enormous numbers of sea-bears (Callorhinus ursinus) and sea-oiters (Enhydra lutris) which frequent the coasts. The climate is foggy, and the vegetation stunted and sparse, while in the neiyhbouring Kamschatkan territory the blue of the summer sky, the stillness of the sea, and the softness of the air, are almost Italian in character. The flora, moreover, is so exuberant tbat numerous plants, which in Norway never exceed two or three feet, here attain the height of a tall man. Next to the birch (Betula ermanni), alders, willows, and roans (Sorbus Kamschaticus), are the most frequent trees, the berries of the last-named, and those of Lonicer a corulea, $\mathrm{p}$ 'ssessing a sweetness which brings them into great request among strangers as well as natives. Some flowers also, as the wild, indigenous, dark red rise, several rh dodendrons, and native lilies, are :qually remarkable for exceptional fragrance. Among wild flowers, some of the geraniuus, potentillas, taraxacums, \&c., are almost identical with those found in Norway. Besides a large whale, and a specimen of the walrus (Rosmarus obesus), which had been killed near Avatscha Bay, Dr. Stejneger could find no trace of any mammal but a small specimen of Arvicola aconomus. Of birds there is, however, an enormous variety, some of which, as Calliope Kamschatica, Carpodacus Erythrinus, and a kind of sedge-warbler, provisionally named by the author "Acrocephalus dybowskii," combine an almost tropical brilliancy of colouring with a sweetness of song equal to that of our own nightingale or thrush. Besides these melodious warblers, Kamschatka harbours large numbers of Locustella lanceolata, whose grasshopper-like cry is heard when all else is still. Cuculus canorinus represents our common cuckoo. Pipits, chats, and wagtails abound; Larus capistratus is commoner than any other gull, and the osprey is not unfrequent. Mosquito-like gnats of vindictive nature swarm in such numbers as to make the pursuits of the field naturalist almost impracticable. The fauna, generally, is palæarctic in character, with a scarcity of American furms which is very remarkable when we consider the vicinity of the western continent.

\section{PHYSICAL HISTORY OF THE DEAD SEA,} THE FORDAN VALLEY, AND PALESTINE

PROF. E. HULL, LL.D., F.R.S., delivered an interesting lecture on the above subject on March 2, in the Theatre of the Royal Dublin Society's premises, Kildare Street. Prof. Hull said:- "There is no country which possesses for us an interest equal to that which I have to treat of this evening. Its religious and historical associations stand alone amongst those of all nations, and will ever maintain in the history of the world an undying import. But while this is true as regards the religious and social aspects of Palestine, I hope to show that in its physical aspect it possesses points of interest which render it unique amongst all countries, and which have attracted to it the attention of naturalists during a lengthened period down to the present day. Probably no country has been so often described. Its physical features have attracted the attention of observers of natural phenomena from Strabo downwards to the recent admirable work of M. Lartet and the Duc de Luynes, to which I am largely indebted. In more recent times we have the observations of Humboldt, of the late Dr. Hitchcock, of Lieut. Lynch of the United States Navy; who carried out a systematic series of soundings over the bed of the Dead Sea, and more recently of the Rev. Dr. Tristram, of Prof. Roth, Burkhardt, and others, including the Survey made by the officers of the Royal Engineer: It is curious however that the remarkable physical phenomenon which renders the Holy Land unique among:t all countries (regarded in its physical aspect) was not discovered till the year 1836-37, when Heinrich Von Schubert and Prof. Koth determined by barometric observations that the surface of the Dead Sea lies no less than 1300 feet below the level of the Mediterranean, a fact not suspected by previous observers. It is the deep depression of the Jordan Valley, deeper by far than any river valley elsewhere, which is the key to the physical history of the whole country ; and in endeavouring to trace out its origin $I$ : hall reproduce in as general a manner as I can the successive phases through which the region bordering the Mediterranean, and extending eastwards towards the Euphrates and southwards to the Dead Sea, has passed. The fundamental basis of the geological formation of Palestine is the gneissic granite, of Archrean age and metamorphic origin, which rises into the mountains of Idumea, and is the rock from which the huge 
monoliths of Egypt have been hewn, such as Cleopatra's Needle' the obelisk of Luxor, and the column; which adorn the Piazza of Venice. This foundation rock formed part of a continental area down to the Carboniferous period, when it was submerged, and a great sanditone formation was spread over it known as "the Nubian sandstone." After another interval of time the sandstone itself was overspread by limestone deposits of Cretaceous and Tertiary age, deposited over the floor of the ancient sea, and down to the close of the Eocene period the waters of the sea overspread the greater portions of Asia Minor, Palestine, and the adjoining districts of the Asiatic and African continents. The first appearance of Palestine and the adjoining districts as a land surface dates from the succeeding Miocene period, when the bed of the sea was upraised into dry land, and at the same period a great fissure corresponding with the line of the Jordan valley was produced. Along this fissure, which has been traced from the Lebanon southward; towards the Gulf of Akaba - the strata on the eastern (or Moabite) side have been relatively elevated: those on the western relatively depressed;-so that the strata on the opposite sides of the Jordan valley and the Dead Sea do not correspond with each other. This great fissure is the key to the physical formation of the whole region, because it gave origin to a river which once flowed down from the mountains of Lebanon-southwards through the Gorge of Arabah (discovered by Burkhardt)-into the Red Sea in a remarkably straight line running north and south for a distance of over 250 miles. This is now the Jordan. The depression of the valley continuing through the succeeding Pliocene epoch, the district of the Ghor and the Jordan valley was conveyed into a lake, which Prof. Hull considered ultimately extended from the southern end of the Dead Sea, northwards nearly to the Lake Merom, and included the Sea of Galilee. This lake would then have had a length of I6o miles and an average breadth of ten miles. During "the Pluvial period," which succeeded "the Glacial," the waters probably reached their maximum elevation, and continued to flow southwards through the Gorge of Arabah and the Gulf of Akaba into the Red Sea ; but from the increasing dryness of the climate they gradually decreased, and the surface of the lake became contracted, and ultimately reduced to its existing limits. During this lowering of the surface, the remarkable terraces noticed by most travellers were formed. Dr. Tristram has taken the barometric level of several of these above the Dead Sea. They range up to 750 feet, and even higher. They appear to be undoubtedly old lake margins, and indicate the successive levels at which the lake stood. The 750-foot terrace very closely correspouds to the summit-level of the Gorge of Arabah. When the waters were reduced so low as not to pass through the Gorge of Arabah, they became brackish, and ultimately salt-the salinity increasing as the area became diminished. All lakes not having an outlet become saline; and the contrast of the waters of the Sea of Galilee and those of the Dead Sea form a striking illu;tration of the law just stated. The saline ingredients in the surface waters of the Dead Sea are 24.57 lbs. in roolbs. of the water, while that of the Atlantic only contains $61 \mathrm{~b}$. . in the same quantity. The Dead Sea water is therefore over four times as strongly impregnated with salts as that of the ocean, and in the deeper waters the salinity amsunts to saturation, as saline deposits are forming over the floor of the D sad Sea. This remarkable inland sea had assumed somewhat of its present contracted dimensions, and was known as "the Salt Sea" as far back as the time of 'the Patriarch Abraham. Near its borders stood the doomed cities of Sodom and Gomorrah-not beneath its waters, as was often supposed-but near its upper margin. With the call of Abraham the political and religious history of Palestine begin;, and the narrative of the physical historian ends

\section{SCIENTIFIC SERIALS}

American Fourna? of Science, March. -The selective absorption of solar energy, by S. P. Langley.-New locality of the green turquois known as chalcuite, and ' on the identity of turquois with the callais or callaina of Pliny, by W. P. Blake. -On portions of the skeleton of a whale from gravel on the line of the Canada Pacific Railway near Smith Falls, Ontario, by J. W. Dawson.-The cobrebs of Uloborus, by J. H. Emerton.-Glacial drift in the Upper Missouri River region, by C. A. White.--Late observations concerning the molluican fauna and the geographical extent of the Laramie group, by the same. - The Sphingidæ of North America, by A. R. Grote."Rotational coefficients" of various metals, by E. H. Hall. Recent exploration of the volcanic phenomena of the Hawaiian islands, by C. E. Dutton.

Journal of the Russian Chemical and Physical Society, vol. xiv. fasc. 9.-On several ethylenic hydrocarbons, and on their action on water, by M. A. Eltekoff. Of the compounds of the series $\mathrm{C}_{\mathrm{n}} \mathrm{H}_{211} \mathrm{O}$, the oxides are the least known, and it still remains in doubt as to those described by MM. Baner, Würtz, Jekyll, and Clermont being true oxides and not ketones ; M. Eltekoff studied, therefore, the action on water of seven compounds of this series. $\mathrm{He}$ arrives at the conclusion that the characieristic features of oxides do not disappear, as seemed formerly to be the case, in more compound oxides containing even as much as six equivalents of carbon. Their capacity of entering in direct compounds with water diminishes, however, in proportion as the mulecule becomes more complicated.-On the oxidation of sulphur used for covering the vineyards, by M. A. Bazaroff.-On the evaporation of liquids, by M. Sreznewsky. Evaporation of benzol, ether, ethyl-alcohol, chloroform, and sulphur of carbon at different temperatures. The paper will be continued.-On the critical temperature and pressure of water, by M. O. Strauss. The average of a series of observations gives for the critical temperature of water $370^{\circ}$, with a probable err of of $5^{\circ}$. The critical pressure would be $195^{\circ} 5$ atmospheres. - Hist rrical sketch of the work accomplished by the Physical Sosiety during its ten years' existence, by M. N. Hesehus. - Oi the te nperature of the absolute vaporisation of liquits, by M. Nadejdin.-On the spheroidal state of liquids, by M. D. Diakonoff.-Minutes of proceedings.

Rivista Scientifico-Industriale e Giornale dsl Naturalista, January I5.-The glossograph of S. Gentilli.-Infuence of ozone in agriculture, by $\mathrm{S} . \mathrm{Zi}$ ino. - The radiometer and sch ool experim nnts, by C. Rovelli. - Fo sil elephants in the district of Parma. - Simple holohedral forms of the rhombohedral system, by M. de Lupo.

Reale Istituto Lombardo di Scienzz e Lettere. Renticonti, vol. xvi. fasc. i.-Meteorological résumé of the year I 882 , calculated on observations made at the Royal Observatory of Brera, by $\mathrm{E}$. Pini.- The frost of 1882 considered in its agrari un and meteoric aspect, by E. Ferrario. - Results of observations on the amplitade of diarnal oscillation of the declination-needle made durin I 882 at Brera Obiervatory, by G. Schiaparelli.-On the action of metallic iodide on leucine and other like substances, by $G$. Körner and E. Menozzi.

Fasc. ii. - l'roperty of a class of functions with more variables than are presented in dynamics in the case of permanent motion, by C. Formenti.-On some plane involution;, by E. Bertini.Generalisation of a theore $n$ on the analytical representation of substitutions, by A. Grandi.

Schriften der Physiralisch.Ökonomischen Gesellschaft zu Konigsberg. I880, fir t part; 1881 , first and second parts. Geological investigation of the North German Jevel country, especially East and West Prussia, in the yeurs I878-80, by A. Jentzsch.-Contributions to a knowledge of the Silurian Cephalopoda found in the East and West Prussian diluvial formations, by $\mathrm{H}$. Schröder.- Rugous corals in the same formation, by $\mathrm{G}$. Meyer. - The scales of our fishes, by B. Benecke.-On some diluvial and alluvial diatom-layers of North Germany, by P. T. Cleve and A. Jentzsch. - The underground portion of the North German level country, by A. Jentzsch.

Verhandlungen der Naturhistorischen Vereinos der Preussischen Rheinlande und Westfalens, 1832 (first half).-Further observations on fertilisation of flowers by insects, by $\mathrm{H}$. Müller. --On the various systems of measurement of elestric and mag. netic quantities, by $R$. Clausius, - The lower Devonian strata of Olkenbach, by O. Follmann.

\section{SOCIETIES AND ACADEMIES LONDON}

Royal Society, March 8.- "Notes on the Absorption of Ultra-Violet Rays by various Substances," by Professors Liveing and Dewar.

These notes contain some records of ultra-violet absarptions in addition to those which have been examined by Soret, 